\title{
Renewable Energy Generation in India: Present Scenario and Future Prospects
}

Singh, Sri Niwas; Singh, Bharat; Østergaard, Jacob

Published in:

IEEE PES General Meeting

Link to article, DOI:

10.1109/PES.2009.5275448

Publication date:

2009

Document Version

Publisher's PDF, also known as Version of record

Link back to DTU Orbit

Citation (APA):

Singh, S. N., Singh, B., \& Østergaard, J. (2009). Renewable Energy Generation in India: Present Scenario and Future Prospects. In IEEE PES General Meeting https://doi.org/10.1109/PES.2009.5275448

\section{General rights}

Copyright and moral rights for the publications made accessible in the public portal are retained by the authors and/or other copyright owners and it is a condition of accessing publications that users recognise and abide by the legal requirements associated with these rights.

- Users may download and print one copy of any publication from the public portal for the purpose of private study or research.

- You may not further distribute the material or use it for any profit-making activity or commercial gain

- You may freely distribute the URL identifying the publication in the public portal

If you believe that this document breaches copyright please contact us providing details, and we will remove access to the work immediately and investigate your claim 


\title{
Renewable Energy Generation in India: Present Scenario and Future Prospects
}

\author{
S. N. Singh, Senior Member, IEEE, Bharat Singh, Student Member, IEEE and Jacob Østergaard, Member, IEEE
}

\begin{abstract}
The development of Renewable Energy Sources (RES) is necessary for the sustainable development of any country due to depleting fossil fuel level, climbing fossil fuel prices across the world and more recently pressure for reduction emission level. In India, several schemes and policies are launched by the government to support the use of RES to achieve energy security and self-sufficiency. This paper discusses the present scenario and future prospects of RES in India. Various schemes such as financial assistance, tax holiday etc for promoting RESs development and utilization are also discussed. The present situation is seen to be very promising and favorable for RES in India.
\end{abstract}

Index Terms-Renewable energy sources, wind power, biomass power, small hydro power, rural village electrification.

\section{INTRODUCTION}

$\mathbf{E}$ NERGY is a prime factor for economic growth, social and industrial development of a country. It is estimated that by the next two decades, the world energy consumption will be two-thirds more than today. India, which is the one of the fastest developing and populous countries of the world, experiences highly economic boom in recent thirty years on the one hand, and on the other, is suffering from huge energy shortage [1]. The role of new and renewable energy sources has been increasing significantly in recent years due to growing energy demand with minimum environmental impact. Renewable Energy Sources (RES) are clean, safe, easy to maintain and sustainable method of generating power.

Almost all the States in India are facing energy shortages in the range of $3 \%$ to $21 \%$ with national average energy shortage of about $10.3 \%$ and shortage in peak demand is $15.4 \%$ [2]. RES can supplement the present supply-demand gap and at the same time, can address the environmental and energy security issues. Renewable energy technologies have a good potential in India and considerable progress has been achieved so far. Substantial efforts at government, public and private levels have been made to harness the non-conventional and renewable sources of energy during the last three decades. As early as in 1981, the Government of India (GOI) established a Commission for Additional Sources of Energy (CASE) under the Department of Science and Technology (DST). The

S. N. Singh (e-mail: snsingh @iitk.ac.in) and Bharat Singh (e-mail: bsraj@iitk.ac.in) are with the Dept. of Electrical Engg., IIT Kanpur, Kanpur 208016, India. Tel: 91-512-2597009; Fax: 91-512-2590063.

Jacob Østergaard (e-mail: joe @oersted.dtu.dk) is with Centre for Electric Technology, Dept. of Electrical Engg., Technical University of Denmark, DK2800 Kgs. Lyngby Denmark. Tel: 45-4525-3501; Fax: 45-4588-6111. commission had the responsibility of formulating policies and their implementation for the development of new and renewable energy apart from coordinating and intensifying R\&D in the sector. In 1982, the commission was given full status of a department called as Department of Nonconventional Energy Sources (DNES) and put at par with other energy departments, such as coal and power.

Finally, in 1992, the GOI upgraded the department to a full-fledged ministry known as Ministry of Non-conventional Energy Sources (MNES) exclusively devoted to the renewable energy promotion and it is renamed as Ministry of New and Renewable Energy (MNRE) in 2006. The vision of Indian renewable energy program is "to develop new and renewable energy technologies, processes, materials, components, subsystems, products and services at par with international specifications, standards and performance parameters in order to make the country a net foreign exchange earner in the sector and deploy such indigenously developed and/or manufactured products and services in furtherance of the national goal of energy security". The MNRE efforts have been identified in following four areas:

* Power generation from renewable

- Grid-interactive renewable power (Wind Power, Small Hydro Power (SHP), Biomass Power, Urban \& Industrial Waste-to-energy and Solar Power),

- Captive/CHP/Distributed Renewable Power (such as Biomass/Cogeneration, Biomass Gasifier, Waste-toenergy, Aero-generator/Hybrid Systems)

* Rural \& Decentralized Energy System (such as Familytype Biogas Plants, Home Lighting System, Solar Photovoltaic (SPV)/Thermal Program, Wind Pumps)

* Remote Village Electrification

* Other programs (such as Energy Parks, Akshay Urja Shops and Hybrid Vehicles)

Renewable energy sources such as wind, solar, biomass and SHP are getting greater recognition in meeting the day-to-day energy requirements for captive power of domestic, commercial and industrial sectors. The renewable energy sector is now an established sector in India with significant installed grid quality renewable power, which has reached 13.8 GW as of September, 2008. A large number of decentralized renewable energy systems such as biogas plants, solar water heating systems, biomass gasifiers, SPV systems, etc. have been promoted under various schemes of the MNRE.

This paper discusses the present status of renewable energy sources development, government policies to promote RES in India. Future perceptive plan of RES in India is also 
highlighted. Tariff policy and specialized centers/institutes are presented.

\section{RENEWABLE ENERGY DEVELOPMENT IN INDIA}

Government of India has created conducive environment for speedy development of RES and to attract private investors by providing subsidy, fiscal incentives, policies support, regulatory \& legislative framework, finances, consultancy services, research design \& development, up-gradation of existing technologies and planning \& resource assessment The Government is mainly a catalyst and facilitator, however, the implementation is being carried out by the States or by the private sector. Many States have so far announced promotional policies for RES. The cumulative achievements of RES are elaborated in Table I [1]. Table II depicted all India total installed capacity [2].

TABLE I

ESTIMATED POTENTIAL AND CUMULATIVE ACHIEVEMENT OF RES AS ON 30.09 .08

\begin{tabular}{lllc}
\hline S. No. & \multicolumn{1}{c}{ Sources/Systems } & $\begin{array}{c}\text { Estimated } \\
\text { Potential }\end{array}$ & $\begin{array}{c}\text { Cumulative } \\
\text { Potential }\end{array}$ \\
\hline $\begin{array}{l}\text { I. Power Generation from Renewable } \\
\text { A. } \text { Grid-interactive Renewable Power }\end{array}$ & \\
\hline 1 & Wind Power & $45195 \mathrm{MW}$ & $9521 \mathrm{MW}$ \\
2 & Biomass Power & $16881 \mathrm{MW}$ & $656 \mathrm{MW}$ \\
3 & (Agro residues) & & \\
& Small Hydro Power & $15000 \mathrm{MW}$ & $2220 \mathrm{MW}$ \\
4 & (up to 25 MW) & $5000 \mathrm{MW}$ & $994 \mathrm{MW}$ \\
5 & Cogeneration Bagasse & $2700 \mathrm{MW}$ & $56 \mathrm{MW}$ \\
6 & Waste-to-energy & & $2 \mathrm{MW}$ \\
\end{tabular}

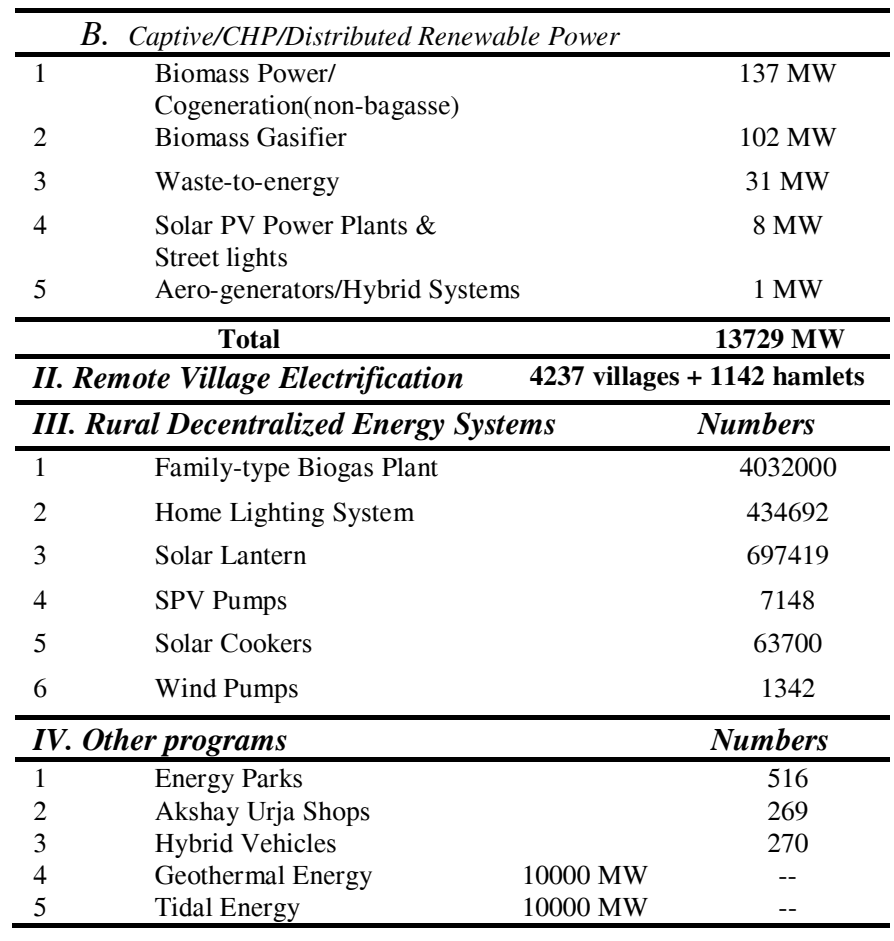

\section{A. Tariff Policy}

The Electricity Act 2003 has paved the way for setting up of State Electricity Regulatory Commissions (SERC) for providing conducive atmosphere for the rapid development of power generation including renewable energy. The National Electricity Policy 2005 stipulates the progressive of electricity generation from non-conventional sources [3-5]. The National Tariff Policy that was notified by the Ministry of Power in January 2006, in continuation with the Electricity Act 2003 and the National Electricity Policy 2005, also emphasizes the importance of setting renewable energy targets and preferential feed-in tariffs for renewable energy procurement by the respective SERC. Several SERC in turn, provided concessional feed-in tariffs (mostly decided by cost-based approach), wheeling (transporting electric power over transmission lines), banking of energy for future use, third party sale and power evacuation facilities, as shown in Table III [1], [6].

TABLE II

ALL INDIA INSTALLED CAPACITY AS ON 30.09.08

\begin{tabular}{llll}
\hline S. No. & Fuel & Share (in MW) & Percentage (\%) \\
\hline 1 & Total Thermal & 92892 & 63 \\
& Coal & 76988 & \\
& Gas & 14704 & \\
& Oil & 1199 & 25 \\
2 & Hydro & 36347 & 9 \\
3 & Renewable & 13729 & 3 \\
4 & Nuclear & 4120 & $\mathbf{1 0 0}$ \\
\hline
\end{tabular}

B. Incentives/Promotion Policies

The MNRE has been providing capital subsidy as Central Financial Assistance (CFA), which varies according to the type and the size of the plants and the category of institutions and areas to promote RES (grid-interactive) as given in Table IV. Besides the CFA, fiscal incentives such as $80 \%$ accelerated depreciation, concessional import duty, excise duty, tax holiday for several years, etc., are available for RES [1], [7-10].

\section{Specialized Centers/Institutes}

MNRE also established and developed several specialized centers to play a major role in providing technical, $R \& D$ and financial back-up for promoting renewable energy programs, such as:

(1) Centre of Wind Energy Technology (CWET), established in 1982, to serves as the technical focal point for wind power development in India [8].

(2) Solar Energy Centre (SEC), established in 1982, is a dedicated unit of the MNRE for development of solar energy technologies and to promote its applications through product development and serves as an effective interface between the Government and institutions, industry \& user organizations for development, promotion and widespread utilization of solar energy in India,

(3) Alternate Hydro Energy Centre (AHEC) was established in 1982, to promote power generation through SHP projects in hilly as well as plain areas. It also caters the development of decentralized integrated energy systems in conjunction with other renewable energy sources e.g. biomass, solar, wind, etc.

(4) Sardar Swaran Singh - National Institute of Renewable Energy (SSS-NIRE) is being established to serve the technical 
focal point for development of bio-energy, including bio-fuels, and synthetic fuels.

(5) Indian Renewable Energy Development Agency Limited (IREDA) was established in 1987. It promotes and finances renewable energy and energy efficiency/conservation projects and has played a significant role in attracting bilateral and multilateral financial assistance from world institutions and the private sectors [11].

TABLE III

PREFERENTIAL TARIFFS/POLICY INTRODUCED ANNOUNCED BY THE SERC'S FOR WIND/BIOMASS/SHP

\begin{tabular}{|c|c|c|c|c|c|c|c|}
\hline Sources & & & ind & & mass/Cogeneratio & & SHP \\
\hline Items & $\begin{array}{l}\text { Wheeling } \\
\text { Charges }\end{array}$ & Banking & Buy-back (INR/kWh) & $\begin{array}{l}\text { Wheeling } \\
\text { Charges }\end{array}$ & Banking & $\begin{array}{c}\text { Buy-back } \\
\text { (INR/kWh) }\end{array}$ & $\begin{array}{c}\text { Buy-back } \\
\text { (INR/kWh) }\end{array}$ \\
\hline $\begin{array}{l}\text { Andhra } \\
\text { Pradesh }\end{array}$ & $2 \%$ of energy & 12 Months & 3.37 & $\begin{array}{c}28.4 \%+ \\
\text { INR } 0.5 \mathrm{kWh}\end{array}$ & $\begin{array}{l}\text { Allowed at } 2 \% \\
\text { for } 8-12 \text { Mont. }\end{array}$ & 2.63 & 2.69 \\
\hline Chhattisgarh & -- & -- & -- & $6 \%$ of energy & Not Allowed & 2.67 & -- \\
\hline Gujarat & $4 \%$ of energy & -- & 3.37 fixed for 20 yrs. & $4 \%$ of energy & Allowed & 3.0 & -- \\
\hline Haryana & $2 \%$ of energy & Allowed & $4.08+$ Escalation $1.5 \%$ & $2 \%$ of energy & Allowed & 4.0 & 2.25 \\
\hline HP & -- & -- & -- & -- & -- & -- & 2.50 \\
\hline Karnataka & $2 \%$ of energy & $\begin{array}{l}2 \% / \text { Month } \\
\text { for } 12 \text { Month }\end{array}$ & 3.40 fixed for 10 years & $5 \%$ surcharge & $\begin{array}{l}\text { Allowed at } 2 \% \\
\text { INR } 1.13 / \mathrm{kWh} \\
\end{array}$ & 2.27 & 2.90 \\
\hline Kerala & $5 \%$ of energy & $\begin{array}{l}9 \text { Months } \\
\text { (Jun.-Feb.) }\end{array}$ & 3.14 fixed for 20 years & $5 \%$ of energy & $\begin{array}{c}\text { Allowed } 4 \\
\text { Months }\end{array}$ & 2.80 & -- \\
\hline Maharashtra & $\begin{array}{l}2 \% \text { of energy } \\
+5 \% \text { trans.loss }\end{array}$ & 12 Months & $\begin{array}{l}3.50+\text { Escalation of } 0.15 \text { for } 13 \\
\text { years from documentation of the } \\
\text { project }\end{array}$ & $7 \%$ of energy & Allowed & 3.05 & 2.25 \\
\hline $\begin{array}{l}\text { Madhya } \\
\text { Pradesh }\end{array}$ & $2 \%$ of energy & $\begin{array}{l}\text { Not } \\
\text { allowed }\end{array}$ & $\begin{array}{l}3.97 \text { (with decrease of } 0.7 \text { upto } \\
4^{\text {th }} \mathrm{yr} \text { ) then fixed at } 3.30 \text { from } \\
5^{\text {th }} \mathrm{yr} \text { onwards uniformly for } 20 \\
\text { years }\end{array}$ & -- & Allowed & 3.33 & 2.25 \\
\hline Punjab & -- & -- & -- & $2 \%$ of energy & $\begin{array}{l}\text { Allowed12 } \\
\text { Months }\end{array}$ & 3.59 & 2.73 \\
\hline Rajasthan & $10 \%$ of energy & 3 Months & $\begin{array}{l}3.59 \text { for Jaisalmer, Jodhpur etc. } \\
\text { and } 3.67 \text { for other districts }\end{array}$ & $10 \%$ of energy & $\begin{array}{c}\text { Allowed } 12 \\
\text { Months }\end{array}$ & 3.60 & 2.75 \\
\hline Tamil Nadu & $5 \%$ of energy & $\begin{array}{c}5 \% \\
12 \text { months } \\
\end{array}$ & 2.90 (Levelised) & $2-10 \%$ & $\begin{array}{c}\text { Allowed at } 2 \% \\
\text { charge }\end{array}$ & 2.73 & -- \\
\hline Uttar Pradesh & -- & -- & -- & $\begin{array}{l}12.5 \% \text { of } \\
\text { energy }\end{array}$ & $\begin{array}{l}\text { Allowed } \\
24 \text { Months }\end{array}$ & 2.67 & 2.25 \\
\hline West-Bengal & INR $0.3 / \mathrm{kWh}$ & 6 Months & $\begin{array}{l}\text { To be decided on case to case } \\
\text { with a cap of } 4\end{array}$ & -- & -- & -- & -- \\
\hline
\end{tabular}

Open access transaction is allowed in all States. Third party sale is allowed in case of wind in all States. RPS is announced in each State

\section{GRID-INTERactive Renewable Power}

Grid interactive renewable power projects are essentially through private investment with Government subsidy. Since renewable power would need to compete with conventional electricity generation, the main focus is towards reducing the capital cost of projects and increasing their capacity factors, with the eventual aim of reducing the unit cost of renewable power generation. India has one of the largest programs in the renewable energy covering wide spectrum of resources such as wind, solar, biomass, SHP, etc.

\section{A. Wind Power}

Wind power program is the highly successful in India's and occupies the fourth position in the world having wind power installed capacity of $9521 \mathrm{MW}$ as on September 2008. GOI policy and regulatory framework both at the State and Central levels are encouraging wind power generation in India. This sector has been growing at over 35\% in the last three years. The wind power program in India was initiated towards the end of the Sixth Plan (1983-84). The program aims at catalyzing commercialization of wind power generation in the country [12].

Wind in India is influenced by the strong south-west summer monsoon, which starts in May-June, when cool and humid air moves towards the land and the weaker north-east winter monsoon, which starts in October, when cool and dry air moves towards the ocean. During the period March to August, wind is uniformly strong over the whole Indian coast, except the eastern coast. Wind speeds during the period November to March are relatively weak, though higher winds are available during a part of the period on the Tamil Nadu coastline. These two monsoon winds make the generation potential in Tamil Nadu much higher than in other States.

TABLE IV

Central Financial Assistance PROvided by Government of INDia

\begin{tabular}{|c|c|c|c|}
\hline S. No. & Sources/Systems & \multicolumn{2}{|c|}{ Central Financial Assistance (in INR) } \\
\hline & & $\begin{array}{l}\text { Special Category States } \\
\text { (NE region, Sikkim, J\&K } \\
\text { HP and Uttaranchal) }\end{array}$ & $\begin{array}{l}\text { Other } \\
\text { States }\end{array}$ \\
\hline 1 & Wind Power & $3 \times \mathrm{MF}$ & $2.5 \times \mathrm{MF}$ \\
\hline 2 & $\begin{array}{l}\text { Biomass Power } \\
\text { (Agro- residues) }\end{array}$ & $0.25 \times \mathrm{MF}$ & $0.20 \times \mathrm{MF}$ \\
\hline 3(i) & $\begin{array}{l}\text { Small Hydro Power } \\
\text { (up to } 25 \mathrm{MW} \text { ) }\end{array}$ & $2.2 \times \mathrm{MF}$ & $1.5 \times \mathrm{MF}$ \\
\hline 3(ii) & $\begin{array}{l}\text { Renovation and } \\
\text { Modernization of SHP }\end{array}$ & $1.125 \times \mathrm{MF}$ & $0.75 \times \mathrm{MF}$ \\
\hline 4 & $\begin{array}{l}\text { Biomass Power using } \\
\text { Advanced Technologies }\end{array}$ & $1.2 \times \mathrm{MF}$ & $1.0 \times \mathrm{MF}$ \\
\hline 5 & $\begin{array}{l}\text { Cogeneration Bagasse } \\
\text { (Private) }\end{array}$ & & \\
\hline 6 & $\begin{array}{l}40 \text { bar } \& \text { above } \\
\text { Cogeneration Bagasse }\end{array}$ & $0.18 \times \mathrm{MF}$ & $15 \times \mathrm{MF}$ \\
\hline & $\begin{array}{l}\text { (Public/joint) } \\
40 \text { bar \& above }\end{array}$ & $\begin{array}{l}0.40 \times \mathrm{MF} \\
0.50 \times \mathrm{MF}\end{array}$ & $\begin{array}{r}0.40 \times \mathrm{MF} \\
0.50 \times \mathrm{MF}\end{array}$ \\
\hline & $\begin{array}{l}60 \text { bar } \& \text { above } \\
80 \text { bar } \& \text { above }\end{array}$ & $0.60 \times \mathrm{MF}$ & $0.60 \times \mathrm{MF}$ \\
\hline 7 & Waste-to-energy & $\begin{array}{l}20 \% \text { higher than other } \\
\text { States }\end{array}$ & $(0.50-1.0) \times 10^{7}$ \\
\hline
\end{tabular}


1) Wind Resource Assessment and Potential: The wind resources assessment program is being implemented through the Field Research Unit of Indian Institute of Tropical Meteorology (IITM-FRU) and CWET. The program has so far covered 25 States and Union Territories involving establishment of 1150 wind monitoring and wind mapping stations having annual average wind power density greater than $200 \mathrm{~W} / \mathrm{m}^{2}$ at $50 \mathrm{~m}$ height. The cost of setting up a wind monitoring station is shared between Central and State governments in ratio of 80:20 whereas it is 90:10 for the North Eastern Region and hilly States. 216 potential sites have been identified in the country. Also, a micro survey around for 97 wind monitoring stations in 10 States to find out the wind environment at every $1 \mathrm{~km}$ laterally and vertically, in 400 square kilometers of area is carried out.

The potential for wind power generation for grid interaction has been estimated at about 45,000 MW on macro level based on data collected from 10 States considering only $1 \%$ land availability. However, technical potential is limited to only $13,000 \mathrm{MW}$ assuming $20 \%$ grid penetrations, which will go up with the augmentation of grid capacity in potential States [8].

2) Wind Power Deployment: The growth of wind power in India from 1996 to 2008 is shown in Fig. 1. A cumulative total of over 46 billion $\mathrm{kWh}$ has been fed to the State Electricity Grids. Out of this total wind power installed capacity, around 95.5\% constitute private projects and the rests are demonstration projects. The MNRE plans to add $10 \mathrm{GW}$ of renewable energy capacity by 2012 and it is hoped that more than $50 \%$ of this capacity comes from wind power. A notable feature of the Indian program has been the interest among private investors/developers in setting up of commercial wind power projects. Wind turbines of 1.0, 1.25, 1.5, and 1.65 MW are being installed across the country in large numbers. Asia's largest wind turbine generator of $2 \mathrm{MW}$ capacity has been installed at Chettikulam in Tirunelveli Dist. of Tamil Nadu [1].

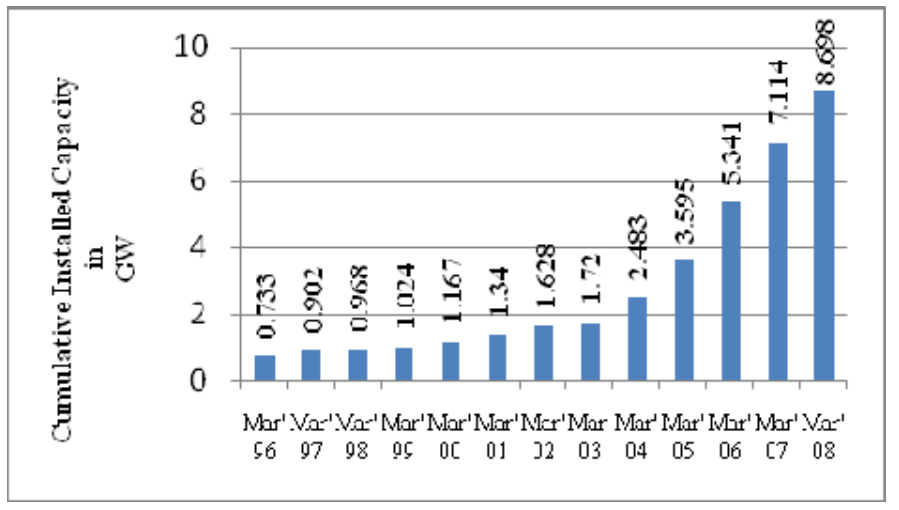

Fig. 1 Growth of wind power in India

Wind Electric Generators are being manufactured in the country by a dozen manufacturers such as Suzlon, Enercon, Vestas, etc. The industry has taken up indigenized production of blades, gearboxes, yaw components, towers etc. An indigenization level up to $50 \%$ has been achieved in machines. A notable characteristic of the previous Indian development was the fact that, by the end of the Indian "wind rush" in the late 1990s, some $70 \%$ of the turbines installed were manufactured in India. Most of the turbines manufactured in this way were made under license from European or American vendors. Few manufacturers have started manufacturing wind electric generators without any foreign collaboration.

The current annual production capacity of domestic wind turbine is about $2000 \mathrm{MW}$. Suzlon is currently the leading manufacturer of wind turbines for the Indian market, holding more than 50 percent of market share in India. Suzlon's success has made India the developing country leader in advanced wind turbine technology. As of 2007 it had captured 10.5 percent of market share in global wind turbine sales and fifth leading wind turbine developer in world [13-16]. A number of support mechanisms in place to support development is described in Table III-V.

TABLE V

IMPLEMENTED FISCAL INCENTIVES FOR WIND/BIOMASS/SHP/SOLAR POWER GENERATION

\begin{tabular}{|l|l|}
\hline \multicolumn{1}{|c|}{ Item } & \multicolumn{1}{|c|}{ Description } \\
\hline Accelerated & $\begin{array}{l}\text { 80\% depreciation in the first year can be claimed for the } \\
\text { following equipment: } \\
\text { for Wind: Extra 20\% after March 2005 for new plant \& } \\
\text { machinery }\end{array}$ \\
& $\begin{array}{l}\text { for Cogeneration Systems: } \\
\text { 1. Back pressure, pass-out, controlled extraction, } \\
\text { extraction-cum-condensing turbine for co- } \\
\text { generation with pressure boilers }\end{array}$ \\
& $\begin{array}{l}\text { 2. Vapour absorption refrigeration systems } \\
\text { 4. Organic rankine cycle power systems }\end{array}$ \\
\hline Tax Holiday & Ten years tax holidays. \\
\hline Customs & $\begin{array}{l}\text { Concessional customs and excise duty exemption for } \\
\text { machinery and components for initial setting up of } \\
\text { puty }\end{array}$ \\
\hline Sales Tax & Exemption is available in certain States \\
\hline
\end{tabular}

\section{B. Biomass Power/Cogeneration Program}

The biomass power/cogeneration program is implemented with the main objective of promoting technologies for optimum use of country's biomass resources such as bagasse, rice husk, straw, cotton stalk, soya husk, de-oiled cakes, wastes, groundnut/coconut shells, saw dust, etc. The main conversion process for power generation from biomass is thermo chemical or biochemical. The thermo-chemical processes involve combustion/cogeneration, gasification or pyrolysis [1].

The availability of biomass in India is estimated at about 540 million tonnes per year covering residues from agriculture, agro-industrial, forestry, and plantations. It has been estimated that using surplus agricultural residues, more than $16,000 \mathrm{MW}$ of grid quality power can be generated with presently available technologies. In addition, about $5000 \mathrm{MW}$ of power can be produced, if all the 550 sugar mills in the country switch over to modern techniques of co-generation. Thus, the country is considered to have a biomass power potential of about 21,000 MW.

The Ministry has been implementing biomass power/cogeneration programs since mid nineties. A total of 167 biomass power and cogeneration projects aggregating to 1650 MW capacity have been installed in the country for feeding 
power to the grid. In addition, around 171 biomass power and cogeneration projects aggregating to $1850 \mathrm{MW}$ of electricity are under various stages of implementation. Cogeneration projects in sugar mills include 82 projects with installed capacity aggregating to $690 \mathrm{MW}$. Another 107 projects are under implementation aggregating to $1280 \mathrm{MW}$. States, which have taken leading position in implementation of cogeneration projects, are Andhra Pradesh, Tamil Nadu, Karnataka, and Uttar Pradesh. The leading States for biomass power projects are Andhra Pradesh, Karnataka, Chhattisgarh, Maharashtra, and Tamil Nadu. A number of support mechanisms in place to support development is described in Table III-V.

\section{Small Hydro Power Program}

SHP Program is one of the thrust areas of power generation from renewable in India. In India, hydro projects up to $25 \mathrm{MW}$ station capacities have been categorized as SHP projects. It has been recognized that small hydropower projects can play a critical role in improving the overall energy scenario of the country and in particular for remote and inaccessible areas. The Ministry is encouraging development of SHP projects both in the public as well as private sector. Equal attention is being paid to grid-interactive and decentralized projects. The subsidy available from the Ministry is linked to use of equipment manufactured to IEC or other prescribed international standards [17].

The Ministry's aim is that $2 \%$ of the total grid interactive power generation capacity should come from mini/small hydro. An estimated potential of about 15,000 MW of SHP projects exists in India. MNRE has created a database of potential sites of SHP it on a GIS platform and 4096 potential sites with an aggregate capacity of $10071 \mathrm{MW}$ for projects up to $25 \mathrm{MW}$ capacities have been identified. The total installed capacity of SHP projects (up to $25 \mathrm{MW}$ ) as on September, 2008 is 2221 MW from 602 projects and 219 projects with aggregate capacity of $650 \mathrm{MW}$ are under construction. A target of adding about $1400 \mathrm{MW}$ during the $11^{\text {th }}$ Plan (20072012) has been fixed. Number of support mechanisms in place to support development is described in Table III-V. Subsidy is also provided for renovation and modernization (R\&M) of existing as well as languishing SHP projects only in the public sector, as shown in Table IV.

\section{Solar Power Generation}

India receives solar energy equivalent to over 5,000 trillion $\mathrm{kWh}$ per year. The daily average solar energy incident varies from 4-7 kWh per square meter depending upon the location. The annual average global solar radiation on horizontal surface, incident over India is about $5.5 \mathrm{kWh}$ per square meter per day. There are about 300 clear sunny days in most parts of the country. MNRE has announced a new initiative on development and demonstration of MW capacity grid interactive solar power generation in January 2008, with a view to harness the vast solar energy potential in the country for power generation. Under the program, MNRE will support grid interactive solar power generation projects up to a maximum capacity of $50 \mathrm{MW}$ [17].
A maximum of $10 \mathrm{MW}$ capacity SPV power generation projects would be considered in a State. Preference would be given to the projects from the States where the SERCs have announced or are in the process of announcing tariff for solar power. In absence of tariff for solar power, the utility should provide the highest tariff offered for medium term power purchase or the maximum tariff fixed for power from any other renewable energy source, till the SERC announces a tariff for solar power, failing which project in that State would not be considered under the demonstration program. The IREDA will assist the Ministry in overall implementation of the program. The gird interactive SPV plant may be connected to preferably $33 \mathrm{kV}$ grid line to minimize power transfer losses. However, the choice of grid voltage may be determined in consultation with the concerned State utility.

\section{E. Energy Recovery from Urban \& Industrial Wastes}

The national program on energy recovery from urban and industrial wastes in India aims at promoting efficient and proven technologies for the treatment, processing and disposal of wastes, not only as a means of improving the waste management practice in the country, but also for augmenting power generation. The major advantages for adopting technologies for recovery of energy from urban wastes is to reduce the quantity of waste and net reduction in environmental pollution, besides generation of substantial quantity of energy. The technological options available for setting up of waste-to-energy projects are anaerobic digestion/ bio-methanation, combustion/incineration, pyrolysis/ gasification, landfill gas recovery and densification/ pelletization. In addition to these technologies, there are other emerging technologies such as plasma arc technology is being attempted for energy recovery from waste.

However, there are a few limitations/constraints, which have limited the growth of this sector such as lack of financial resources, policy guidelines, etc. Moreover, the waste-toenergy is still a new concept in the country. Recent developments in municipal solid waste management would facilitate promotion of projects for recovery of energy from urban wastes. According to a recent estimate, about 42 million tonnes of solid waste $\left(1.15 \times 10^{5}\right.$ tonnes per day) and 6000 million cubic meters of liquid waste are generated every year by our urban population. Three projects for energy recovery from municipal solid wastes with an aggregate capacity of 17.6 MW have been installed at Hyderabad, Vijayawada and Lucknow. Total 8 projects for energy recovery from urban wastes with an aggregate capacity of 19.05 MWe have been set up.

\section{OFF-GRID RENEWABLE POWER}

\section{A. Small Wind Energy \& Hybrid Systems}

Small wind energy systems viz. water pumping windmills, aero-generators and wind-solar hybrid systems are useful for meeting water pumping and small power requirements in rural/semi-urban/ urban windy areas of the country. Under the program, a cumulative total of 1342 water-pumping windmills have, so far, been installed, which includes 55 windmills. An aggregate capacity of $675.27 \mathrm{~kW}$ of aero-generators/hybrid 
systems has been installed under the program. The rated capacity of individual aero-generators covered under the program will be up to a maximum of $30 \mathrm{~kW}$ indigenously manufactured/assembled aero-generators.

\section{B. Decentralized SHP Projects}

Realizing the fact that mini hydro power projects can provide a solution for the energy problem in rural, remote and hilly areas where extension of grid system is comparatively uneconomical. A number of mini/micro hydro projects have been set up in remote and isolated areas, mainly in Himalayan region. While these projects are developed by various State agencies responsible for renewable energy, the projects are normally maintained with local community participation. A number of tea garden owners have also set up such micro hydro projects to meet their captive requirement of power.

Water wheels have traditionally been used in the Himalayan regions for rice hulling, milling of grain and other mechanical applications. These water mills are normally of very old design and work at very low efficiencies. It has been estimated that there are more than $1.5 \times 10^{5}$ potential water mill sites in the Himalayan regions of India. A number of NGOs are now propagating water mills for electricity generation to meet small scale electrical requirements of villages. The state of Uttaranchal has taken a lead in setting up electricity generation watermills and over 500 such watermills were installed in remote and isolated areas of the State.

\section{Solar PV Power Plants}

Photovoltaic (PV) cells, commonly known as solar cells, are used to convert light (photon) in to electricity. A country wide SPV program is being implemented by the Ministry for more than two decades. The following SPV systems are covered under the SPV programs of MNRE:

* Solar Home Lighting Systems/Solar Home Systems

* Solar Lanterns and Street Lighting Systems

* Stand-alone PV power plants/ water pumping systems

* Other applications of SPV Technology including new applications.

PV modules and systems of about 335 MWp cumulative capacity have been utilized by 31st March, 2007, for various applications. Under the SPV program, about $11 \times 10^{5}$ systems have been installed. This includes $7 \times 10^{5}$ solar lanterns, 4.34 $\times 10^{5}$ solar home lighting systems, 59000 street lighting systems, 7148 water pumping systems and of about $10.13 \mathrm{MW}$ aggregate capacity of standalone and grid interactive SPV power plants.

\section{REMOTE VILLAGE ELECTRIFICATION}

The Remote Village Electrification Program (RVEP) of the Ministry aims at providing basic lighting/electricity facilities through renewable energy sources in those un-electrified remote census villages and remote un-electrified hamlets of electrified census villages where grid connectivity is either not feasible or not cost effective. About 4237 un-electrified census villages and 1142 un-electrified hamlets of electrified villages have so far been provided with basic lighting/electricity facilities. About $90 \%$ of the project cost of the projects is met through a CFA for meeting the total domestic and community energy requirements. The balance $10 \%$ towards the project cost is to be mobilized by the community/ implementing agency/State Nodal Agency. A Village Energy Fund (VEF) is also created with initial contribution from the villagers.

\section{RuRAl \& DeCEnTRALIZED RENEWABLE POWER}

Nearly 73 percent of India's population lives in more than $5.5 \times 10^{5}$ villages. The Ministry has been supporting programs for the use of renewable energy products and devices such as biogas plants, solar thermal systems, photovoltaic devices, biomass gasifiers, etc.

\section{A. Family-type Biogas Plant}

Biogas is a clean and efficient fuel which contains about 65 per cent methane, about 34 percent carbon dioxide and traces of other gases, such as hydrogen sulphide and ammonia. Biogas is produced when organic materials, such as cattle dung, are digested in the absence of air, in 'Biogas Plant'.

The Central sector scheme on National Biogas Program, which mainly caters to setting up of family type biogas plants, has been under implementation since 1981-82. National Biogas \& Manure Management Program provides for Central subsidy in fixed amounts, turn-key job fee linked with three years free maintenance warranty, financial support for repair of old-non functional plants, training of users, masons, entrepreneurs, etc., publicity and extension, service charges or staff support. Biogas can be used for cooking, lighting, and power generation.

\section{OTHER PROGRAMS}

\section{A. Renewable Energy Park Scheme}

The Renewable Energy Park Scheme (REPS) was started in 1994-95 under the Special Area Demonstration Program (SADP). The main objective of the REPS is to create awareness, publicity and provide an opportunity to the students/teachers and rural and urban masses about the use and benefits of the renewable energy by demonstrating new and renewable energy systems. Two types of renewable energy parks are being supported under this scheme namely District Level Renewable Energy Parks (DLEP) and State Level Renewable Energy Parks (SLEP). DLEPs are set up at Educational Institutions, Krishi Vigyan Kendras, Registered Consumer Forums, registered NGOs with facilities for Science and Environment Education and public places where there is large inflow of public. SLEP is set up in a State at a location where large flow of people and tourists takes place every day.

The scheme provides for two DLEP in a district and one SLEP per State. Under the scheme, the Ministry has so far supported 26 SLEP and 478 DLEP in 32 States/Union Territories. So far, 14 State level Renewable Energy Parks and 232 district level Renewable Energy Parks have been completed. Out of 610 Districts, 337 districts have so far been covered and 273 districts have yet to be covered. A typical DLEP may include energy systems/devices such as, improved Chulhas (fixed/portable type), SPV street lights, domestic lights and solar lanterns, solar water heating systems, solar cookers, solar stills, biogas plant, SPV radio, SPV power 
plant, a SPV color television, a SPV pump, a solar drier, a biomass gasifier and a wind pump.

\section{B. Akshay Urja Shops}

A revised scheme on establishment of Akshay Urja Shops is under implementation under which shops are being established by NGOs, State Nodal Agencies, Manufacturers' Associations and entrepreneurs, one per district. Loans up to INR $10 \times 10^{5}$ through designated banks can be availed for establishment of the shops with an interest subsidy of $4 \%$. In addition, recurring grant and incentive linked with turnover up to INR 10,000 per month during the first two years of operation is also available. The scheme is in operation through State Nodal Agencies and IREDA. Up to 12 Akshay Urja Shops in 2 States have been sanctioned so far during the year, taking the total to 269 Shops in 29 States/Union Territories, which includes 104 Aditya Solar Shops established under the earlier scheme.

\section{Hybrid Vehicles}

MNRE has also sanctioned a pilot project for demonstration and field performance evaluation of about 300 battery-operated three-wheelers. These are based on a combination of the engine of a conventional vehicle with electric motor powered by traction batteries and/or fuel cells.

Prototypes of Nickel Metal Hydride (NiMH) batteries have been developed with indigenously available alloys and tried on electric bikes. The MNRE has been implementing a demonstration program on battery operated electric vehicles through the State Nodal Agencies and Departments.

\section{Alternative Fuels}

Already a $50 \mathrm{~kW}$ Phosphoric Acid Fuel Cell (PAFC) power plant has been tested for distributed power generation and a fuel cell vehicle based on an indigenously developed proton exchange membrane fuel cell (PEMFC) system is being operated for demonstration, education, and performance evaluation in Chennai. Hydrogen fueled power-generating sets, two-wheelers and catalytic burners for industrial and residential usage have been developed and demonstrated. Hydrogen powered vehicles and fuel cell vehicles are truly zero-emission vehicles.

\section{E. Geothermal \& Tidal Energy}

In India, exploration and study of geothermal fields started in 1970. The Geological Survey of India (GSI) has identified 350 geothermal energy locations in the country. The most promising of these is in Puga valley of Ladakh. The estimated potential for geothermal energy in India is about $10 \mathrm{GW}$. There are seven geothermal locations in India: the Himalayas, Sohana, West coast, Cambay, Son-Narmada-Tapi (SONATA), Godavari, and Mahanadi [18]. Ongoing Projects in India are at Magneto-telluric investigations in Tattapani geothermal area in Madhya Pradesh and Magneto-telluric investigations in Puga geothermal area in Ladakh region, Jammu \& Kashmir. Potential applications are power generation cooking, space heating, greenhouse cultivation, and crop drying.

Since India is surrounded by sea on three sides, its potential to harness tidal energy has been recognized by the GOI. The most attractive locations are the Gulf of Cambay and the Gulf of Kachchh on the west coast. The identified economic tidal power potential in India is of the order of $10 \mathrm{GW}$. Detailed Project Report for setting up of a 3.65 MW Tidal Power Project at Durgaduani, Sunderbans, West Bengal and $900 \mathrm{MW}$ Kachchh Tidal Power Project has been prepared. The technoeconomic feasibility report is now being examined [19].

\section{Future PERSPECTIVE OF RENEW ABLE ENERGy IN INDIA}

\section{A. Perspective Plan 2022}

The Integrated Energy Policy Report (IEPR), prepared by the planning commission of India, has recognized renewable energy sources remain important to Indian's energy sector. It would not be out of place to mention that solar power could be an important player in India attaining energy independence in the long run. With a concerted push and a 40 fold increase in their contribution to the primary energy, renewables may account for only 5-6\% of India's energy mix by 2031-32. While this figure appears small, the distributed nature of renewables can provide many socio-economic benefits. This will call for extensive RD\&D efforts to make renewable energy technologies more reliable, long life and cost effective. The planning commission of India set a very competitive goal for India in its perspective plan 2022.

1) Perspective Plan for Grid-interactive Renewable Power: The aim for the $11^{\text {th }}$ five year plan i.e (2007-12) is a capacity addition of 15000 MW from RES (14000 MW Gridinteractive and $1000 \mathrm{MW}$ distributed RES). By the end of the $11^{\text {th }}$ plan, renewable power capacity would be $25000 \mathrm{MW}$ in a total capacity of $200 \mathrm{GW}$ accounting for $12.5 \%$ and contributing around 5\% to the electricity mix. A capacity addition of around $30 \mathrm{GW}$ is envisaged for the $12^{\text {th }}$ and $13^{\text {th }}$ plans. Renewable power capacity by the end of the $13^{\text {th }}$ plan period is likely to reach $54000 \mathrm{MW}$, comprising $40000 \mathrm{MW}$ wind power, $6500 \mathrm{MW}$ SHP, and $7500 \mathrm{MW}$ bio-power, which would correspond to a share of $5 \%$ in the then electricity-mix. The perspective plan for grid-interactive renewable power is summarized in Table VI [20].

TABLE VI

PERSPECTIVE Plan FOR GRID-INTERACTIVE RENEWABLE POWER FOR 2022 I.E END OF $13^{\text {TH }}$ PLAN PERIOD (IN MW)

\begin{tabular}{|l|c|c|c|c|}
\hline \multicolumn{1}{|c|}{ Resource } & $\begin{array}{c}\text { Upto } 10^{\text {th }} \text { Plan } \\
(2002-07)\end{array}$ & $\begin{array}{c}11^{\text {th }} \text { Plan } \\
(2007-12)\end{array}$ & $\begin{array}{c}12^{\text {th }} \& 13^{\text {th }} \text { Plan } \\
(2012-22)\end{array}$ & Total \\
\hline Wind Power & 7000 & 10500 & 22500 & $\mathbf{4 0 0 0 0}$ \\
\hline SHP & 1960 & 1400 & 3140 & $\mathbf{6 5 0 0}$ \\
\hline Bio Power & 1037 & 2100 & 4363 & $\mathbf{7 5 0 0}$ \\
\hline Solar Power & 3 & - & - & $\mathbf{3}$ \\
\hline Total & $\mathbf{1 0 0 0 0}$ & $\mathbf{1 4 0 0 0}$ & $\mathbf{3 0 0 0 3}$ & $\mathbf{5 4 0 0 3}$ \\
\hline
\end{tabular}

2) Perspective Plan for Renewable Energy for Urban, Industrial, and Commercial Applications: The major goals include 50 million $\mathrm{m}^{2}$ of solar collector area for thermal applications, mainly solar water heating and $7500 \mathrm{MW}$ of grid/captive power from bio-resources, including urban and industrial wastes. Compared to the status in 2007 , there is a massive build-up in capacity, which will require concerted action across various fronts, starting with the next plan. The targets proposed for 2012 and indicative goals for 2022 and 
2032 are reflected in the perspective plan given in Table VII [20].

TABLE VII

PERSPECTIVE PLAN FOR RENEWABLE ENERGY FOR URBAN, INDUSTRIAL, AND COMMERCIAL APPLICATIONS

\begin{tabular}{|l|l|c|c|}
\hline \multicolumn{1}{|c|}{ Resource } & \multicolumn{1}{|c|}{2012} & \multicolumn{1}{c|}{2022} & \multicolumn{1}{c|}{2032} \\
\hline $\begin{array}{l}\text { Solar Thermal } \\
\text { Systems / Devices }\end{array}$ & $\begin{array}{l}10 \text { million } \mathrm{m}^{2} \\
\text { collector area }\end{array}$ & 30 million $\mathrm{m}^{2}$ & 50 million $\mathrm{m}^{2}$ \\
\hline $\begin{array}{l}\text { Energy-efficient } \\
\text { Buildings }\end{array}$ & $\begin{array}{l}5 \text { million } \mathrm{m}^{2} \\
\text { floor area } \\
(1000 \text { buildings })\end{array}$ & 20 million $\mathrm{m}^{2}$ & 40 million $\mathrm{m}^{2}$ \\
\hline $\begin{array}{l}\text { Energy Recovery } \\
\text { from Urban \& } \\
\text { Industrial Wastes }\end{array}$ & $\begin{array}{l}\text { Included in the proposed targets for bio-power in } \\
\text { Table VI. }\end{array}$ \\
\hline
\end{tabular}

\section{B. Medium Term (2032) Deployment Aims}

GOI aims for several medium/long term goals such as $10 \%$ grid interactive renewable power by 2012 and $15 \%$ by 2032, alternate fuels (bio fuels, synthetic fuels, and hydrogen) substitution up to $5 \%$ by 2017 and $10 \%$ by 2032 . The other massive plans in various sectors are

- Energy recovery from municipal waste in 423 cities including 107 municipal corporations where suitable waste is available by 2032 .

- Solar water heating systems: $100 \%$ coverage of all prospective users like hotels, hospitals, etc. by 2032 .

- $100 \%$ coverage of street lighting control systems by solar sensors in all cities by 2012 .

- Energy recovery from industrial wastes: where suitable waste is available across the country by 2032

- Solar water heating systems: $100 \%$ coverage of potential industries by 2032

- Cogeneration: 100\% coverage of potential sugar and other biomass based industries by 2032

- Provision of lighting/electricity in all remote unelectrified census villages and remote hamlets of electrified census villages by 2012

- Augmentation of cooking, lighting and motive power in electrified villages by 2032

\section{CONCLUSIONS}

India has huge potential for producing power from Renewable Energy Sources (RES). Over the last few decades, in particular, Government of India has endeavored to lay the foundation for a broad-based renewable energy program and designed it specially to meet the growing energy needs, and to fulfill energy shortage and security concerns of the country. Considerable experience and capabilities exist in the country on renewable technologies. Although at present the contribution of renewable energy is small, but future developments might make RES technology more competitive to displace conventional energy sources. Prospects for RES are steadily improving in India towards a great future. It is destined to take a leading role in the global renewable energy movement aiming towards sustainable development. The strategy for achieving these enhanced goals will mainly depend on the active participation of all players i.e. from government agencies to NGO's, from manufactures to R\&D institutions, from financial institution to developers and of course a new breed of energy entrepreneurs.

\section{REFERENCES}

[1]. Ministry of New and Renewable Energy, Government of India. [Online] Available: http://www.mnes.nic.in/

[2]. Ministry of Power, Government of India. [Online] Available: http://powermin.nic.in/

[3]. The Electricity Act 2003

[4]. Discussion Paper on "Promotion of Co-generation and Generation of Electricity from Renewable Sources of Energy" Central Electricity Regulatory Commission (CERC), New Delhi, May 2008. [Online] Available: http://cercind.gov.in/index.html

[5]. TERI Report to CERC on "Pricing of power from Non-Conventional Sources" [Online] Available: http://cercind.gov.in/index.html

[6]. P. Deo and S. Modak, Electricity Reforms \& Green Power Development-Regulatory and Tariff Issue, World Institute of Sustainable Energy 2005, India.

[7]. Consolidated Energy Consultants Ltd. (CECL). [Online] Available: http://www.windpowerindia.com/

[8]. Centre for Wind Energy Technology. [Online] Available: http://www.cwet.tn.nic.in/default.htm

[9]. L. G. Lee, "Wind energy developments: Incentives in selected countries,".Available: http://tonto.eia.doe.gov/ftproot/ features/ wind.pdf

[10]. J. I. Lewis and R. H. Wiser, "Fostering a renewable energy technology industry: An international comparison of wind industry policy support mechanisms," Energy Policy, Vol. 35, 2007, pp. 1884-1857.

[11]. Indian Renewable Energy Development Agency (IREDA). [Online] Available: http://www.ireda.in/

[12]. G. M. Pillai, Editor, Wind Power Development in India, World Institute of Sustainable Energy 2006, India.

[13]. J. I. Lewis, "Technology Acquisition and Innovation in the Developing World: Wind Turbine Development in China and India," Studies in Comparative International Development (SCID), Vol. 42, Numbers 3-4, December, 2007, pp. 208-232.

[14]. M. C. Mabel and E Fernandez, "Growth and future trends of wind energy in India," Renewable and Sustainable Energy Reviews, Vol. 12, Issue 6, August 2008, pp.1745-1757.

[15]. Suzlon Energy [Online] Available: http://www.suzlon.com/

[16]. Indian Wind Energy Association (IWEA) [Online] Available: http://www.inwea.org/index.htm

[17]. Annual Report 2007-08, Ministry of New and Renewable Energy, Government of India. [Online] Available: http://mnes.nic.in/ annualreport/2007_2008_English/index.htm

[18]. Indian Energy Portal [Online] Available http://www.india energyportal.org/index.php

[19]. Gujarat Electricity Development Agency (GEDA) [Online] Available http://www.geda.org.in/

[20]. Report of the Working Group on, "NEW AND RENEWABLE ENERGY" for XIth Five Year Plan (2007-12), Planning commission, Government of India, 2006, [Online] Available: http://planning commission.nic.in/aboutus/committee/wrkgrp11/wg11_renewable.pdf

\section{BIOGRAPHIES}

S. N. Singh (SM'02) received M. Tech. and Ph.D. from Indian Institute of Technology Kanpur, India in 1989 and 1995, respectively. Presently, he is working as Professor in the Dept. of Electrical Engg. at Indian Institute of Technology Kanpur, India. His research interests include power system restructuring, power system optimization \& control, and wind power. He is a fellow of the Institution of Engineers (India) and IETE (India) and senior member of IEEE.

Bharat Singh (S'07) received the M. Tech. Degree in 2005 from the Indian Institute of Technology Roorkee, India. Currently, he is a Research Scholar in the Dept. of Electrical Engg. at Indian Institute of Technology Kanpur, India. His research interests include power electronics and grid integration of renewable energies.

Jacob Østergaard is Centre Head and Professor with Centre of Electric Technology in the Dept. of Electrical Engg. at Technical University of Denmark. His research interests include electric power systems, renewable energy, wind power, network and control architectures in electric power systems, electricity demand and integration of energy systems. $\mathrm{He}$ is a member of the advisory council of the EU technology platform, SmartGrids and IEEE. 